Canadian Journal of Fisheries and Aquatic Sciences 1996, v.53, n.9, pp.2067-2075. ISSN: 0706-652X

doi:10.1139/cjfas-53-9-2067

http://pubs.nrc-cnrc.gc.ca/rp-ps/journalDetail.jsp?jcode=cjfas\&lang=eng

http://article.pubs.nrc-

cnrc.gc.ca/RPAS/rpv?hm=HInit\&calyLang=eng\&journal=cjfas\&volume=53\&afpf=f96-140.pdf (C) 1996 All rights reserved. National Research Council of Canada. 


\title{
Effects of sperm irradiation and heat shock on induction of gynogenesis in muskellunge (Esox masquinongy) ${ }^{1}$
}

\author{
Feng Lin and Konrad Dabrowski
}

\begin{abstract}
We report here the first induction of gynogenesis in esocid fish by UV irradiation and heat shock. Optimal dosage of sperm UV irradiation was in the range of $1440-2160 \mathrm{~J} / \mathrm{m}^{2}$. Eggs fertilized with irradiated sperm at such dosages and not heat shocked yielded $100 \%$ abnormal larvae with the fertilization rate at $48.3 \pm 8.4 \%$ (mean $\pm \mathrm{SD}$ ). There were no significant differences in survival to the eyed stage under the heat shock conditions tested (5-30 min post-fertilization for 5-30 min at $26-30^{\circ} \mathrm{C}$ ). Gynogens were induced in most of the groups with hatching rates at $0.2-3.3 \%$. Optimal conditions for gynogenetic induction of muskellunge (Esox masquinongy) were the application of $30^{\circ} \mathrm{C}$ for $8-10 \mathrm{~min}$ beginning $20 \mathrm{~min}$ post-fertilization, with a yield of gynogens at 5.8-6.0\% (hatched normal larvae/viable eyed-stage embryos). Ploidy was identified by chromosome preparation, silver staining for nucleolar organizer regions, and flow cytometry measurement of the nuclear DNA content using eyed-stage embryos and larvae. Haploids hatched but died within 1 week.
\end{abstract}

Résumé : Dans cet article, nous faisons état de la première gynogénèse induite chez les Éspcodés par rayonnement UV et choc thermique. La dose optimale d'irradiation du sperme était de l'ordre de 1440 à $2160 \mathrm{~J} / \mathrm{m}^{2}$. Les oeufs fécondés avec le sperme irradié à ces doses et qui n'ont pas reçu de choc thermique donnaient $100 \%$ de larves anormales à un taux de fécondation de $48,3 \pm 8,4 \%$ (moyenne \pm écart standard). Nous n'avons observé aucune différence significative au niveau de la survie jusqu'au stade embryonné dans les conditions de choc thermique utilisées (5-30 min après la fécondation, pendant 5-30 min, à $26-30^{\circ} \mathrm{C}$ ). Des sujets gynogénotes ont été obtenus dans la plupart des groupes à un taux d'éclosion de $0,2-3,3 \%$. Chez le maskinogé (Esox masquinongy), les conditions optimales pour l'induction de la gynogénèse sont l'application de la chaleur $\left(30^{\circ} \mathrm{C}\right.$ pendant $8-10 \mathrm{~min}$, traitement débutant $20 \mathrm{~min}$ après la fécondation); dans ces conditions, le rendement en sujets gynogénotes est de 5,8-6,0\% (larves normales écloses/embryons viables jusqu'au stade oeillé). Le degré de ploïdie a été déterminé par la préparation des chromosomes, la coloration argentique des régions des organisateurs nucléolaires et par la mesure par cytométrie de flux du contenu en ADN nucléolaires et par la mesure par cytométrie de flux du contenu en ADN nucléaire des embryons oeillés ou des larves. Les sujets haploïdes naissaient, mais mour aient en 1 semaine.

[Traduit par la Rédaction]

\section{Introduction}

Gynogenesis in fish has been studied intensively in the past few decades for its potential value in experimental genetics and aquaculture (see reviews by Thorgaard 1983; Ihssen et al. 1990). Gynogenesis can be achieved by retention of the second polar body or suppression of the first mitotic division of eggs inseminated with irradiated spermatozoa. Gynogenetic fish have been successfully produced in many species, such as rainbow trout (Oncorhynchus mykiss) (Chourrout 1982), common carp (Cyprinus carpio) (Komen et al. 1988), tilapia (Oreochromis mossambicus) (Varadaraj 1990), yellow perch (Perca flavescens) (Malison et al. 1993), and loach (Misgur-

Received October 6, 1995. Accepted March 29, 1996.

$\mathrm{J} 13102$

F. Lin and K. Dabrowski. ${ }^{2}$ School of Natural Resources, The Ohio State University, 2021 Coffey Road, Columbus, OH 43210 , U.S.A.

1 Manuscript No. 165/96 of the School of Natural Resources, The Ohio State University, Columbus, Ohio.

2 Author to whom the correspondence should be addressed. nus anguillicaudatus) (Arai et al. 1993). Spermatozoa from related fish species can also be used to initiate embryonic development (Chourrout 1986). However, low survival of eggs activated and treated to produce gynogens coupled with inbreeding deficiency limit the direct application of this technique (Dunham 1990). A combination of gynogenesis and sex reversal can be used to overcome these problems. This procedure has also been used for producing all-female populations of grass carp (Ctenopharyngodon idella) (Shelton 1986).

Muskellunge (Esox masquinongy) is one of the most popular sport fishes in the north-central United States and central Canada. Annual stocking of this species is required to meet the demands of anglers because of its failure to reproduce naturally in many reservoirs (Dombeck et al. 1984). Like many economically important cool-water species, muskellunge exhibits sexually related dimorphic growth (Scott and Crossman 1973), where femal es reach total length of 760 $\mathrm{mm}$ in 3 years, whereas males require 4 years in Clear Fork Reservoir, Ohio (Day and Stevenson 1989). Males have a higher mortality than females at age 4 and older. Thus, stocking all female muskellunge potentially increases stocking efficiency thereby benefiting the sport fishery. Unfortunately, little knowledge of reproductive physiology and genetics of 
this species is available. McGregor (1970) described karyotypes of muskellunge with an air-drying technique using kidney cells from juvenile fish. Galat (1973) reported the gross normal embryonic development from fertilization until hatching by analyzing preserved specimens, while Leslie and Gorrie (1984) gave a general description of the early life history of muskellunge.

The aim of our study was to investigate methods for producing all-female muskellunge by using gynogenesis. We evaluated effects of temperature and storage times on the viability of muskellunge eggs to facilitate fertilization in controlled, laboratory conditions. We report here the induction of gynogenetic muskellunge by UV irradiation of sperm and heat shock of embryos.

\section{Materials and methods}

Gravid muskellunge females and running ripe males were captured by trap nets from the Clear Fork Reservoir, Ohio, in 1993 and 1994. The captured fish were maintained in a floating pen for a few hours before being stripped of gametes. Gametes were collected from unanesthetized fish, and semen was kept on ice before use. Eggs were kept in a foam box where, as a result of a storage experiment, temperature was maintained at approximately $12^{\circ} \mathrm{C}$. Sperm motility was checked before experimentation (Lin and Dabrowski 1996), and only semen with $>90 \%$ initial motility was used for irradiation or fertilization. Semen from three to five males and eggs from two or three females were pooled before fertilization. Eggs were fertilized with fresh semen to serve as a control for gamete quality in each experiment. Survival to the eyed stage was obtained by counting and removing white (dead) eggs at 7-9 days post-fertilization.

\section{Egg handling and storage}

Previous experience revealed that storage of muskellunge eggs directly on ice during transportation reduced their quality. Hence, an experiment quantifying temperature effect and duration of storage on egg quality was conducted. Eggs from three individual females (about 600 eggs from each) were fertilized with freshly collected sperm at Clear Fork Reservoir immediately after egg collection. Eggs pooled from three females were kept in sealed plastic bags filled with oxygen immediately after collection at Clear Fork Reservoir. Three bags (each with about $100 \mathrm{~mL}$ of eggs) were then dispersed among three shelves of a foam box with ice in the bottom shelf, thus creating three levels of temperature. Three subsamples of eggs were removed from the bags and fertilized after 2,5 , and $8 \mathrm{~h}$ of storage, and the temperatures of the eggs were recorded. The temperatures of eggs on different shelves were 13.6-16.7, 10.1-13.1, and $6.0-7.1^{\circ} \mathrm{C}$ during the experiment. Replicated samples of eggs were incubated separately in PVC jars with a screen bottom, which were set up in California-type hatching trays (Flex-a-lite Consolidated, Tacoma, Wash.). Water temperature was $12-13^{\circ} \mathrm{C}$ during incubation. Survival of embryos to the eyed stage, approximately 6 7 days, was used as a criterion to evaluate egg quality.

\section{UV irradiation for sperm inactivation}

Semen $(0.5 \mathrm{~mL})$ was diluted with $4.5 \mathrm{~mL}$ of $0.75 \% \mathrm{NaCl}$ and $0.6 \% \mathrm{KCl}$ (Varadaraj 1990). A portion $(0.5 \mathrm{~mL})$ of diluted semen was placed on ice to serve as a control for the effect of dilution and storage on sperm fertility. Approximately $300 \mathrm{eggs}$ were fertilized with $0.25 \mathrm{~mL}$ of diluted semen immediately (control 1) and $20 \mathrm{~min}$ after dilution (control 2). The remaining diluted semen was poured into a watch glass and UV irradiated with a short wave $(254 \mathrm{~nm})$ mineralight lamp (Model UVG-11, UVP, Inc., San Gabriel, Calif.) at $6 \mathrm{~W} / \mathrm{m}^{2}$. The intensity of UV irradiation was measured using an UVX radiometer (UVP, Inc., San Gabriel, Calif.) with a sensor
Table 1. Schedule for the effects of temperature and duration of heat shock starting 20 min post-fertilization at $12^{\circ} \mathrm{C}$.

\begin{tabular}{crrrrr}
\hline Temperature $\left({ }^{\circ} \mathrm{C}\right)$ & \multicolumn{5}{c}{ Duration of heat shock (min) } \\
\hline 26 & 10 & 15 & 20 & 25 & 30 \\
28 & 6 & 8 & 10 & 15 & 20 \\
30 & 2 & 4 & 6 & 8 & 10 \\
\hline
\end{tabular}

placed at the same level as the sperm suspension. Sperm suspension was kept on ice and continuously stirred with a magnetic stirrer during the irradiation. Subsamples $(0.25 \mathrm{~mL})$ of the sperm suspension were removed and used to fertilize batches of 300 eggs at 2, 4, 6, 8, $12,16,20$, and $30 \mathrm{~min}$ after dilution and UV irradiation. After 3-5 min of water hardening, each batch of eggs was further divided into three groups and incubated in California-type hatching trays with recirculating water at $12^{\circ} \mathrm{C}$. The fertilized eggs were kept in the dark because damaged sperm DNA could be partially photorepaired by exposure to visible light (Thorgaard 1983). Survival to the eyed stage and hatching were recorded with abnormal larvae considered as mortality.

\section{Heat shock to inhibit the second meiosis}

Eggs were fertilized with irradiated spermatozoa $\left(2000 \mathrm{~J} / \mathrm{m}^{2}\right)$ as described above. After water hardening, eggs were divided into PVC jars with a screen bottom. The first experiment was designed to estimate effects of initial time of heat shock on polar body retention. The jars were transferred to temperature regulated water baths of 26 and $28^{\circ} \mathrm{C}$ at $5,10,15,20,25$, and $30 \mathrm{~min}$ post-fertilization for 10 and $20 \mathrm{~min}$, then returned to the hatching trays for incubation. Fluctuation of water temperature was controlled within $0.1^{\circ} \mathrm{C}$, and water was circulated to ensure a homogeneous temperature in each bath. A second experiment was designed to determine optimal temperature level and duration of heat shock. Eggs were shocked at three temperatures for various times, starting at $20 \mathrm{~min}$ post-fertilization (Table 1). One jar that was not heat shocked served as a negative control. Another batch of eggs was fertilized with diluted semen ( $4 \mathrm{~min}$ on ice) as a control for eggs and sperm quality. Eggs were incubated and survival to the eyed stage and hatching was estimated.

\section{Chromosome preparation and silver staining for nucleolar orga- nizer regions}

Slides were prepared by a modified method of Kligeman and Bloom (1977) and Chourrout and Happe (1986). Briefly, eyed-stage embryos were incubated in $0.02 \%$ colchicine overnight, then the embryos were dissected from the yolk in physiological saline. Embryos were fixed with ethanol : acetic acid (3:1) for at least $2 \mathrm{~h}$ on ice after a hypotonic treatment in $0.8 \%$ sodium citrate for $30 \mathrm{~min}$ at room temperature. Individual embryos were minced in $50 \%$ acetic acid and the cell suspension was dropped onto prewarmed slides. Slides were stained in $10 \%$ Giemsa for chromosomes. Slides for nucleolar organizer regions (NORs) were prepared in the same way, or without colchicine and hypotonic treatment, as for chromosome preparation. Silver staining followed the method of Phillips et al. (1986). The number of nucleoli from 200 randomly selected cells was recorded in each of 6 abnormal fish as well as 6 control fish.

\section{Flow cytometry measurement of DNA content}

Random samples from several groups, including normal and abnormal embryos and larvae, were examined. Embryos and larvae were dissected from their yolks and individually added to $1 \mathrm{~mL}$ incubation solution in a $12 \times 75 \mathrm{~mm}$ culture tube (Malison et al. 1993). The incubation solution contained $50 \mathrm{mg}$ propidium iodide and $10 \mathrm{mg}$ ribonuclease A in $1 \mathrm{~L}$ Hematall (Fisher, catalogue No. CS606-20). Rainbow trout red blood cells were used as an external standard as 
well as added to the incubation solution as an internal standard. Fresh blood was collected from an individual rainbow trout for all measurements. Stained embryos and larvae were syringed through 21- and 25 -g needles after overnight incubation at dark in a $4^{\circ} \mathrm{C}$ refrigerator. Cell suspensions were filtered through $60-\mu \mathrm{m}$ nylon filters before being run through an Elite flow cytometer (Coulter Corporation, Hialeah, Fla). Fluorescence, forward scatter, and $90^{\circ}$ scatter were measured and data were stored as a listmode file. At least 10000 events (cells) were recorded for each sample. Electronic gating was applied to exclude the doublets in calculating the distribution of fluorescence. Cell cycle was analyzed with a computer program, Multicycle (Phoenix Software, San Diego, Calif.).

\section{Data analysis}

All values were expressed as mean and standard deviation. Statistical significance was assessed by a two-way analysis of variance (ANOVA) using the GLM procedure in $\mathrm{SAS}^{\mathrm{TM}}$ version 6.07 (SAS Institute Inc., SAS Campus Drive, Cary, N.C.).

\section{Results}

Embryo survival in muskellunge eggs fertilized immediately after gamete collection amounted to $58.9 \pm 17.9 \%(n=3$ females). We did not include these data in statistical comparisons with experimental treatments because individual rather than pooled samples of eggs were incubated. Eggs stored at intermediate temperatures $\left(10-13^{\circ} \mathrm{C}\right)$ had the highest survival rate to the eyed stage (Fig. 1). Muskellunge eggs stored for 8 $\mathrm{h}$ at $10-13^{\circ} \mathrm{C}$ had less than $30 \%$ mortality. This temperature range was the intermediate water temperature at the capture sites over the season $\left(8.5-15.0^{\circ} \mathrm{C}\right)$. Low temperature $\left(6-7^{\circ} \mathrm{C}\right)$ significantly increased egg mortality $(P<0.01)$. High temperature, $13.6-16.7^{\circ} \mathrm{C}$, had a less negative impact on egg fertility and survival than low temperature.

In the experiment using UV irradiation to inactivate the sperm, eggs fertilized with fresh undiluted semen that served as egg quality controls had $84.6 \pm 2.5 \%$ survival to the eyed stage. Survival to the eyed stage was $43.4 \pm 2.9 \%$ for control 1 (fertilized immediately after dilution; Fig. 2) and $12.9 \pm$ $0.5 \%$ for control 2 (fertilized $20 \mathrm{~min}$ after dilution). Irradiation at a dose greater than $720 \mathrm{~J} / \mathrm{m}^{2}(2 \mathrm{~min})$ resulted in total abnormal embryonic development. Eggs inseminated with sperm irradiated for $6 \mathrm{~min}$ had the highest survival to the eyed stage $(54.7 \pm 4.2 \%)$. Abnormal embryos can be identified morphologically starting from 7 to 9 days post-fertilization based on embryo size and shape, malformed eye, shortened body, and curved tail region (Fig. 3A). Most of the abnormal embryos hatched, but larvae were small and deformed (Fig. 3C) and died within a week.

Chromosome preparations verified that abnormal embryos were haploid, $n=25$, whereas normal embryos had 50 chromosomes. Silver staining for NORs showed that cells of abnormal embryos and larvae had only one $(89.9 \pm 4.5 \%)$ or no NORs $(10.1 \pm 4.5 \%)$, whereas cells from normal embryos and larvae had two $(51.3 \pm 1.7 \%)$, one $(41.5 \pm 2.7 \%)$, or no NORs $(7.2 \pm 2.1 \%)(n=6 ;$ Fig. 4$)$. The maximum number of nucleoli was one for the haploid cells, and two for the diploid cells. Thus, silver staining for NORs could be a reliable method for ploidy identification.

The fluorescent peak from normal embryos and larvae had a mean channel number of 308 (relative DNA content), whereas the peak from abnormal embryos and larvae had a mean of 160 (Fig. 5). The DNA content of haploid cells was half $(0.507)$ that of diploid cells after calibration with internal standards. This supported NOR data that the abnormal embryos and larvae were haploids. All the normal embryos and larvae had a diploid peak while all the abnormal embryos and larvae had a haploid peak $(n=45)$. Cell cycle analysis by computer revealed that the haploid cells had a substantial $\mathrm{G}_{2}$ peak, cells in the interphase II and mitosis of a cell cycle. The cells at each stage of the cell cycle were $82.0,11.9$, and $5.1 \%$ for $G_{1}$ (interphase I), $S$ (DNA synthesis), and $G_{2}$, respectively. The $\mathrm{G}_{2} / \mathrm{G}_{1}$ ratio, representing relative DNA content of these two cell populations, was 1.979. Electronic gating ensured that this peak did not result from cell aggregation. However, such $G_{2}$ peaks were not detected in normal diploid cells. Data used for cell cycle analysis were collected without an internal standard to avoid interference from the standard peak of rainbow trout red blood cells.

In the heat shock experiments, eggs fertilized with diluted but not irradiated semen, which served as an egg quality control had an average survival to eyed stage of $77.7 \pm 7.5 \%$. Eggs in all heat shock groups as well as negative control, groups that were activated by UV irradiated sperm and not heat shocked had similar survival to the eyed stage in both experiments (Figs. 6 and 7). There was no significant difference in survival to the eyed stage among all experimental groups. This indicated that heat shock under such conditions did not have a severe impact on egg viability. However, the average survival of all experimental groups, $58.0 \pm 11.1 \%$ (Fig. 7), was significantly lower than that of controls with non-irradiated semen $(77.7 \%)$. This suggested that the process of semen irradiation rather than heat shock was the major cause for increased mortality.

All embryos in the negative control group hatched as abnormal larvae. This indicated that the UV irradiation effectively destroyed the genetic material of the sperm but retained the ability of sperm to induce the development of eggs. Such eggs developed abnormally without subsequent heat shock but normally when heat shock was given. Further, the abnormal embryos and larvae were shown to be haploids by flow cytometery, while the normal embryos and larvae were diploids. Therefore, the heat shock must have caused duplication of chromosomes in eggs fertilized with UV irradiated sperm.

Gynogens were induced in most of the heat shock groups with hatching rates of $0.2-3.3 \%$. The yield of gynogens was the ratio of hatched normal larvae to the viable eyed stage embryos. The highest yield of gynogens was $6.0 \%$ with heat shock at $30^{\circ} \mathrm{C}$ for $8 \mathrm{~min}$ starting at $20 \mathrm{~min}$ post-fertilization (Fig. 8). There was a significant effect of heat shock temperature and time after fertilization on yield of gynogens $(P<$ 0.01) (Figs. 8 and 9).

\section{Discussion}

Fertilization rates from eggs pooled from several females should represent the mean for the population being sampled. There is no evidence in the literature that pooling samples of eggs from several females influences their fertilization rate in comparison with the average fertilization rate of eggs from individual females. We conclude that the fertilization rate of fresh gametes and that of gametes stored at the optimal tem- 
Fig. 1. Effects of temperature and duration of egg storage on embryo survival. Temperatures were high: $13.6-16.7^{\circ} \mathrm{C}$; middle: $10.1-13.1^{\circ} \mathrm{C}$; low: $6.0-7.1^{\circ} \mathrm{C}$. Eggs were fertilized at 2,5 , and $8 \mathrm{~h}$ after collection. Bars with the same letters are not significantly different at $P=0.05$.

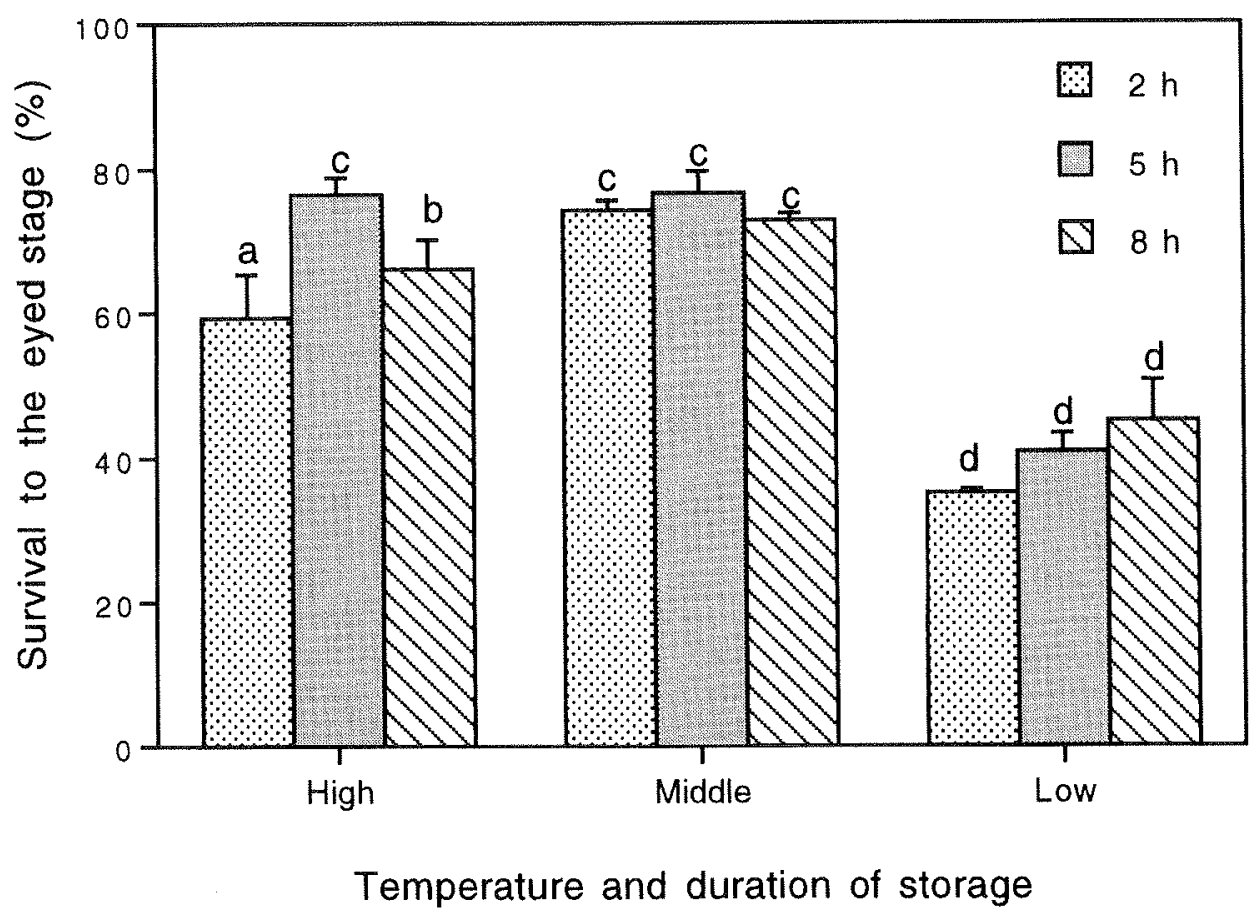

Fig. 2. Effects of dilution and irradiation time on survival of eggs inseminated with irradiated spermatozoa. UV intensity was $6 \mathrm{~W} / \mathrm{m}^{2}$. Larvae with deformed bodies were not counted as normal hatching. Eggs fertilized with semen immediately after dilution without any UV exposure are shown at 0 irradiation time (control 1). Eggs fertilized with semen 20 min after dilution but not irradiated (control 2$)$ had $12.9 \pm 0.5 \%$ survival (not shown).

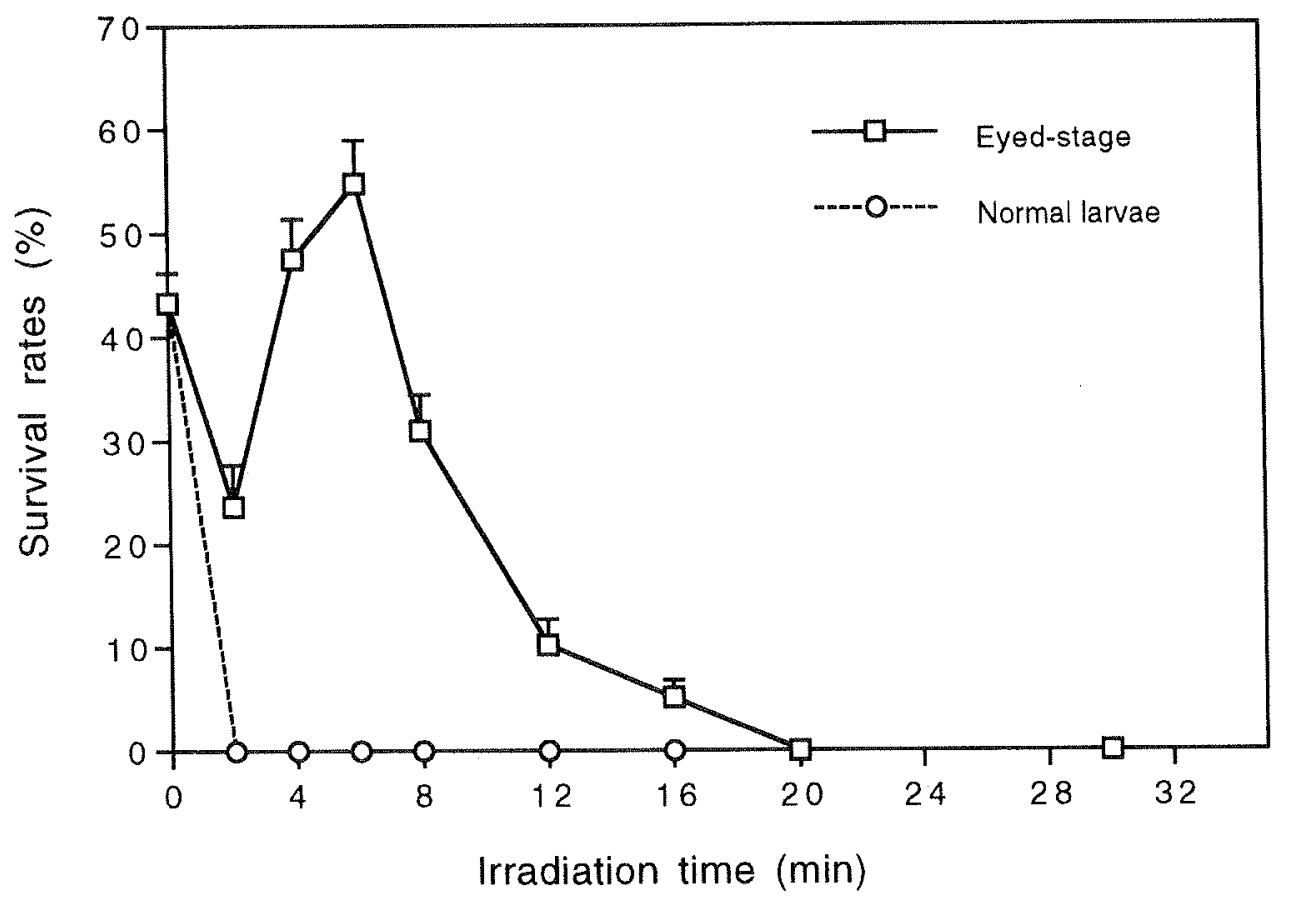



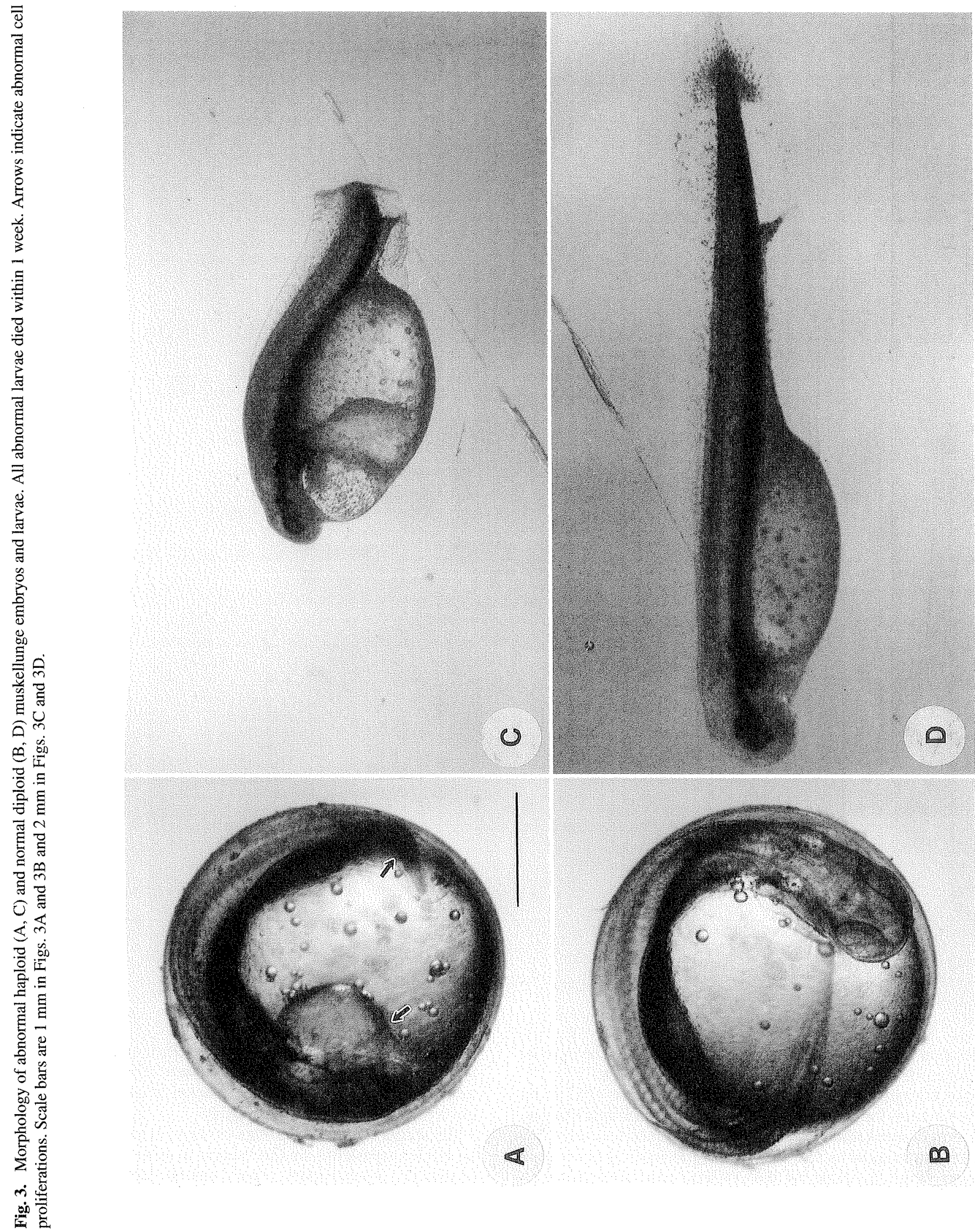

变 
Fig. 4. Nucleolar organizer regions of diploid and haploid cells prepared from normal and abnormal eyed stage embryos: (A) haploid, with a maximum of one nucleolus; (B) diploid, with a maximum of two nucleoli.

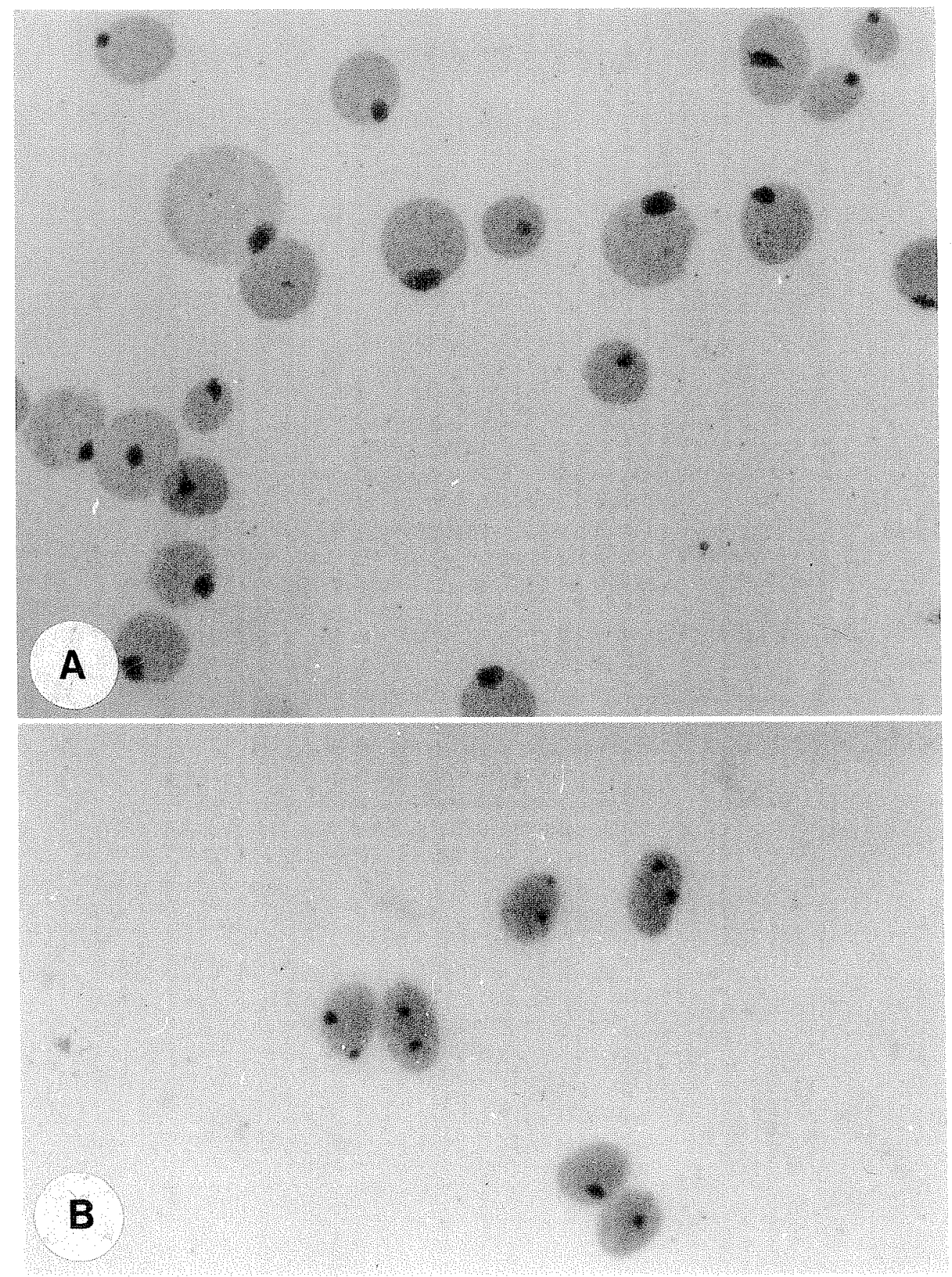

perature in all our experiments was comparable. The optimal temperature of egg storage for muskellunge was $10-13^{\circ} \mathrm{C}$ from the egg storage experiment. Thus, we chose $12^{\circ} \mathrm{C}$ as the temperature for the storage of eggs in our other experiments. Sperm of muskellunge stored on ice for $5 \mathrm{~h}$ and used for fertilization resulted in $76.6 \pm 3.1 \%(n=3)$ survival to the eyed stage (Fig. 1), close to the average rate of fertilization obtained from other experiments in our laboratory $(78 \%$; Lin et al. 1996). There was no significant difference in survival of embryos between 2 and $8 \mathrm{~h}$ of storage (both eggs and sperm) within intermediate- and low-temperature groups. Therefore, we conclude that the impact of duration of sperm storage on ice in this experiment was negligible.

Regarding temporary storage of eggs, Kuchnow and Foster (1976) reported a similar finding to ours in mummichog (Fundulus heteroclitus). They found fertility of eggs remained high for $24 \mathrm{~h}$ at the optimal temperature range $\left(6-10^{\circ} \mathrm{C}\right)$, whereas eggs showed reduced or no fertility when 
Fig. 5. Representative fluorescent distribution of cells prepared from diploid and haploid embryos measured by a flow cytometer. Rainbow trout red blood cells were used as an internal standard. The haploid peak of muskellunge had a mean fluorescence intensity at channel No. 160 ; the diploid peak of muskellunge had a mean fluorescence intensity at channel No. 308; and the internal control of rainbow trout red blood cells had a mean fluorescence intensity at channel No. 642 .

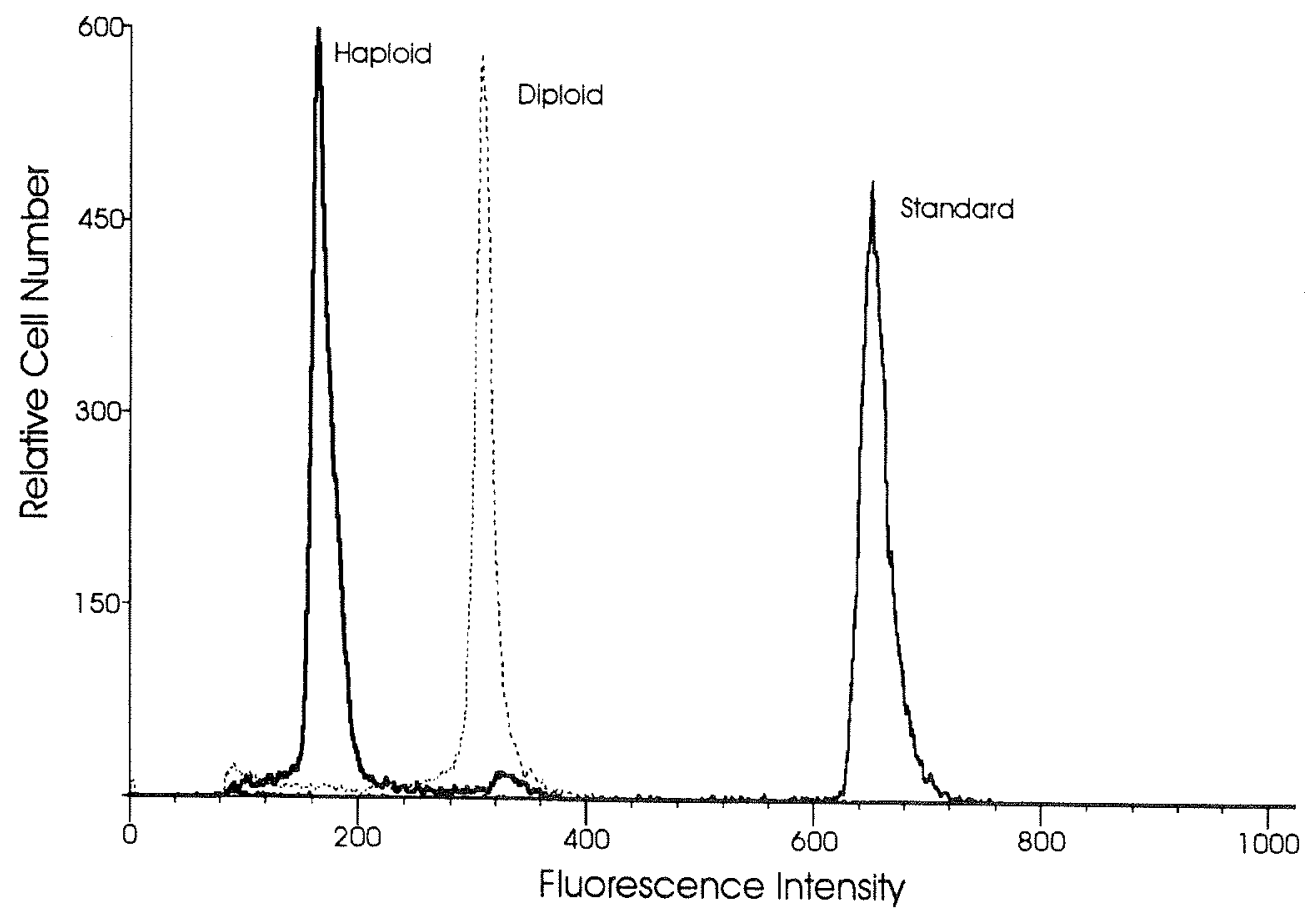

Fig. 6. Effects of initial time of heat shock on the survival to the eyed stage. Eggs fertilized with UV irradiated spermatozoa were heat shocked at 26 and $28^{\circ} \mathrm{C}$ for 10 and 20 min starting at different post-fertilization times. Control (C) was a negative control with UV irradiated sperm but not heat shock.

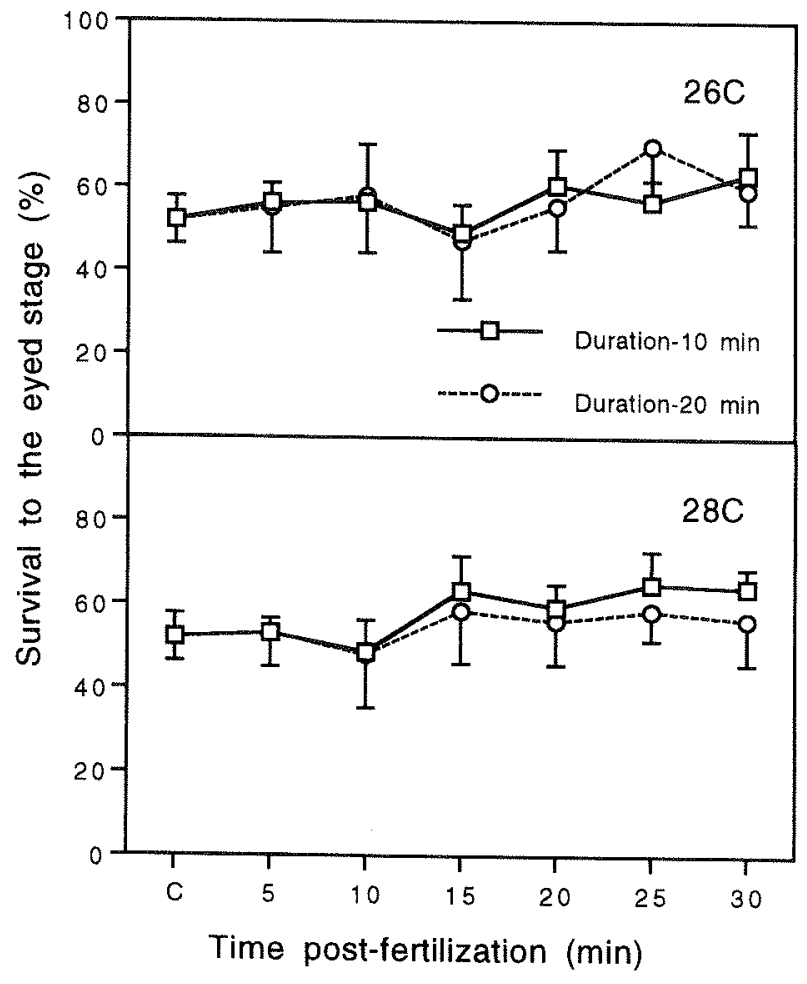

Fig. 7. Effects of temperature and duration of heat shock on the survival to the eyed stage. Eggs that were fertilized with UV irradiated spermatozoa were heat shocked starting at $20 \mathrm{~min}$ post-fertilization at 26,28 , and $30^{\circ} \mathrm{C}$ for various durations according to Table 1. Duration time of zero was the negative control for UV irradiation.

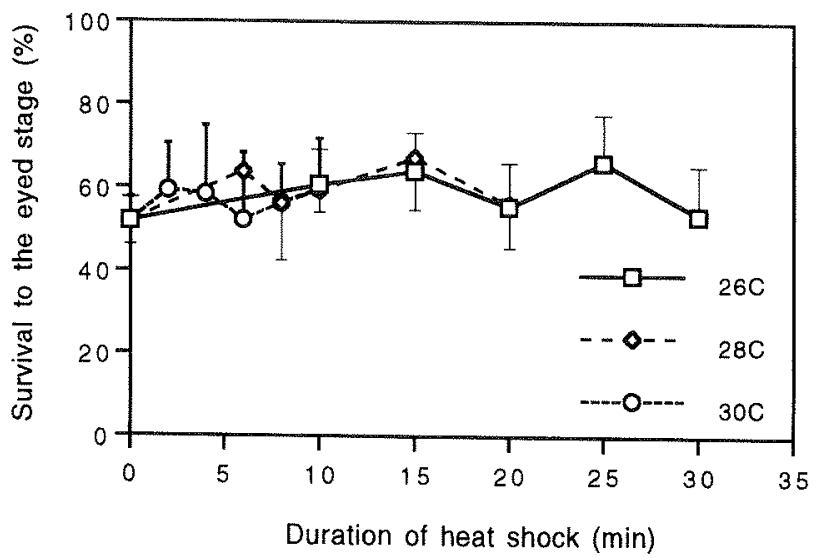

stored at temperatures below $6^{\circ} \mathrm{C}$. Low storage temperature was not suitable for sturgeon (Acipenser guldenstadti), which showed no fertility of eggs stored at $0^{\circ} \mathrm{C}$ (Ginsburg 1972; cited in Stoss 1983). However, storage of salmonid eggs at temperatures of $0-4^{\circ} \mathrm{C}$ has always been superior to storage at a higher temperature. Salmonid eggs of several species have been successfully stored for a few days in ovarian fluid at low temperatures (see review by Stoss 1983). There is yet no 
Fig. 8. Effects of temperature and duration of heat shock on yield of gynogens. Eggs that were fertilized with UV irradiated spermatozoa were heat shocked starting at 20 min post-fertilization at 26,28 , and $30^{\circ} \mathrm{C}$ for various durations according to Table 1 . Duration time of zero was the negative control for UV irradiation.

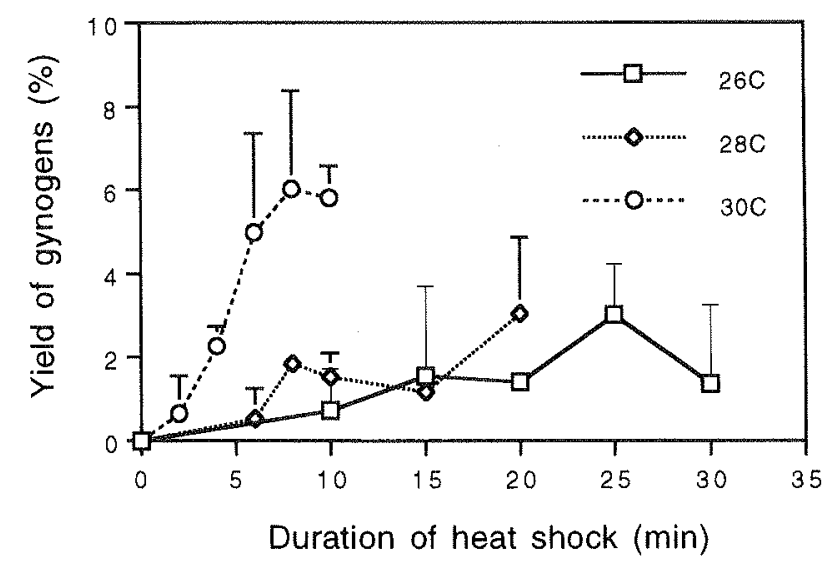

Fig. 9. Effects of initial time of heat shock on yield of gynogens. Eggs fertilized with UV irradiated spermatozoa were heat shocked at 26 and $28^{\circ} \mathrm{C}$ for 10 and $20 \mathrm{~min}$ starting at different post-fertilization times. Control (C) was negative control with UV irradiated sperm but not heat shock. Yield of gynogens is the ratio of normal larvae to the viable eyed stage embryos.

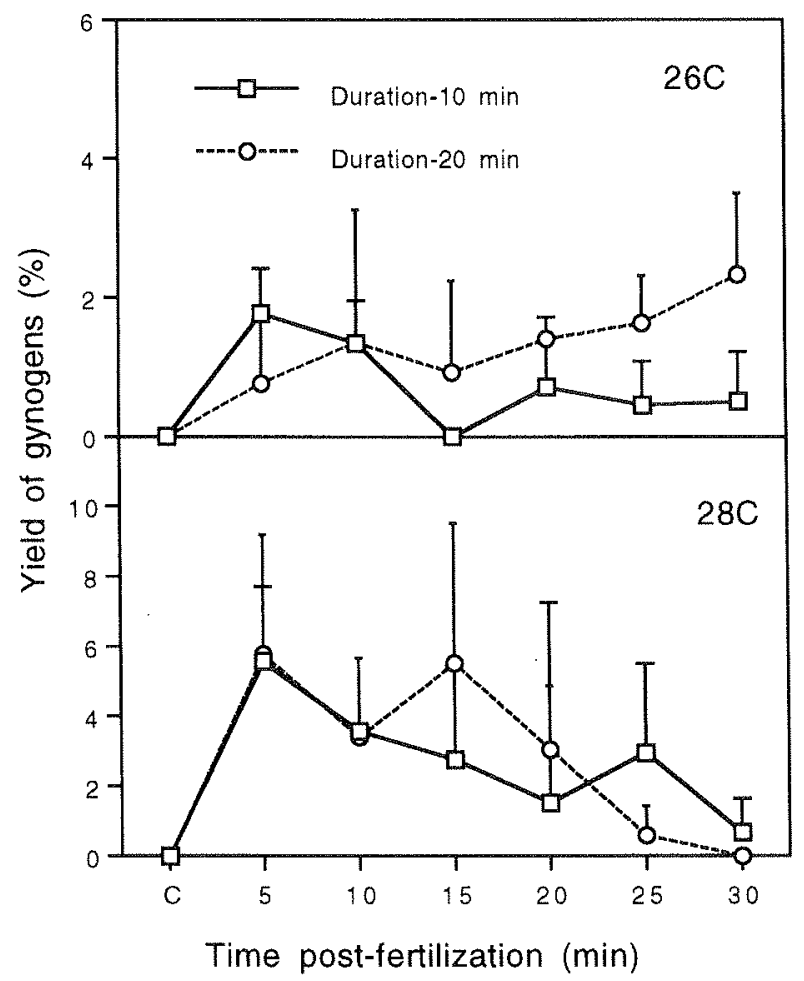

explanation for the differences in desirable storage temperatures among various fish species.

The optimal condition for UV irradiation was considered to be in the range of $1440-2160 \mathrm{~J} / \mathrm{m}^{2}(4-6 \mathrm{~min})$ with a fertilization rate at $48.8 \pm 8.4 \%$. At this UV exposure, sperm retained their ability to activate egg development while sperm DNA was inactivated completely. At a low dosage of $720 \mathrm{~J} / \mathrm{m}^{2}$ (2 min), genetic material of sperm might not be completely destroyed and interfere with embryonic development, thus causing relatively low survival to the eyed stage. We found that UV irradiation of eggs (for androgenesis) at a marginal dosage resulted in malformations in embryonic development and simultaneous decrease in DNA content in comparison with diploid controls (F. Lin and K. Dabrowski, unpublished data). This phenomenon revealed a typical "Hertwig effect" (Thorgaard 1983), when haploid embryos resulting from total destruction of the genetic material in the sperm by high levels of radiation would survive longer than diploid embryos expressing dominant lethal mutations induced by radiation. Prolonged exposure to UV ( $>8 \mathrm{~min}$ ) and stirring during irradiation reduced the insemination ability of sperm (Fig. 2). The decreasing survival of eggs fertilized with semen immediately after dilution (control 1) and 20 min later (control 2) indicated that dilution and keeping the diluted semen on ice had a negative impact on sperm fertility. Thus, duration of irradiation should be kept short to avoid loss of sperm fertility. A high-power UV lamp can be used to improve efficiency of exposure and to shorten the irradiation time. A better diluent for sperm irradiation is also desirable.

We verified that all normal hatched larvae examined, using chromosome preparation, silver staining of NORs, and flow cytometry measurement of DNA content, were diploids while all abnormal larvae were haploids. Thus, haploids and diploids could be identified by their morphology. The chromosome preparation for muskellunge is time-consuming and well-spread metaphase chromosomes can only be obtained during a specific period of embryonic development. A similar situation was reported in rainbow trout (Chourrout and Happe 1986). We provided evidence that silver staining of NORs was a reliable method for ploidy identification in muskellunge with each set of chromosomes containing only one NOR in this species. Silver staining of NORs has been used to identify ploidy levels in salmonids (Phillips et al. 1986), cyprinids (Sola et al. 1986; Carman et al. 1992), and most recently in comparing different species of esocoid (Rab and Crossmon 1994).

Flow cytometry measurement of DNA content is a quick and accurate method for ploidy identification. It has several advantages over other methods because it can also detect aneuploidy and mosaic individuals. We found that a significant percentage of $\mathrm{G}_{2}$ peak $(5.1 \%$ ) was present in haploid individuals, whereas $\mathrm{G}_{2}$ peak was undetectable in the diploid individuals. Since electronic gating eliminated the possibility of doublets in cell suspension of haploids, another explanation could be that the mitosis and interphase II phases accounted for a very small portion of the cell cycle in diploid cells. Thus, $\mathrm{G}_{2}$ peak was hard to detect because most of the cells were at the stage of interphase $I\left(G_{1}\right.$ or $\left.G_{0}\right)$. Haploid cells might have an abnormal cell cycle with a longer cycle time and a relatively larger portion staying at interphase II and mitosis phases. Thus, haploid individuals had a smaller number of cells (smaller and deformed embryos).

Gynogenetic muskellunge were induced by heat shock in most of the experimental groups. A broad range of heat shock conditions (temperature $26-30^{\circ} \mathrm{C}$; initial time of heat shock 5-30 $\mathrm{min}$ post-fertilization; duration 5-30 $\mathrm{min}$ ) inhibited the extrusion of the second polar body at a rate of $0.4-6 \%$. Heat 
shock at $30^{\circ} \mathrm{C}$ for $8-10 \mathrm{~min}$ starting at $20 \mathrm{~min}$ post-fertilization appeared to be optimal for induction of chromosome duplication in muskellunge. Luczynski and Woznicki (1995) reported a successful induction of triploids in the northern pike (Esox lucius); up to $50 \%$ triploids with $50 \%$ survival compared with control groups, using a heat shock at $28^{\circ} \mathrm{C}$ for $10 \mathrm{~min}$ starting at $10 \mathrm{~min}$ post-fertilization. The survival to hatching in our study was $0.2-3.3 \%$ and the highest yield of gynogens was only $6 \%$. It is possible that changes in heat shock conditions could improve the yield of gynogens, but an increased temperature or duration of the heat shock might also result in a high mortality and an increased risk of damage of the genetic material of eggs. Low survival of eggs was found in the muskellunge (our unpublished data) as well as in the northern pike (Luczynski and Woznicki 1995) when eggs were treated at $32^{\circ} \mathrm{C}$ for retention of the second polar body. Thus, the use of relatively low-intensity heat shock $\left(30^{\circ} \mathrm{C}\right.$ for 8-10 $\mathrm{min}$ ) for chromosome duplication remains the preferable option.

The low yield of gynogens and hatching rate does not preclude mass production of gynogenetic muskellunge because the fish has a high fecundity. The abnormal haploid fish are eliminated soon after hatching because they do not survive through yolk-sac absorption. Because gynogenetic fish are not desirable for direct stocking into natural water bodies, a small number of gynogenetic muskellunge females is required for sex reversal and then phenotypic males can be used as broodstock in producing all-female populations.

\section{Acknowledgments}

We would like to thank Jennifer Tomsen of the School of Natural Resources, The Ohio State University, for her critical reading of this manuscript. We appreciate helpful cooperation in sampling gametes from Richard Day, Frank Kapler, and Bruce Bartens of the Ohio Division of Wildlife. Joseph $O$. Trask, Jr., of the Comprehensive Cancer Center offered technical help in operating the flow cytometer. This work was funded by the Federal Aid in Sport Fish Restoration Program (F-69-P, Fish Management in Ohio) administered jointly by the United States Fish and Wildlife Service and the Ohio Division of Wildlife. Salaries were partly provided by the State and Federal Funds appropriated to the Ohio Agriculture Research and Development Center and the Piketon Research and Extension Center.

\section{References}

Arai, K., Matsubara, K., and Suzuki, R. 1993. Production of polyploids and viable gynogens using spontaneously occurring tetraploid loach, Misgurnus anguillicaudatus. Aquaculture 117: 227-235.

Carman, O., Oshiro, T., and Takashima, T. 1992. Variation in the maximum number of nucleoli in diploid and triploid common carp. Nippon Suisan Gakkaishi, 58: 2303-2309.

Chourrout, D. 1982. Gynogenesis caused by ultraviolet irradiation of salmonid sperm. J. Exp. Zool. 223: 175-181.

Chourrout, D. 1986. Use of grayling sperm (Thymallus thymallus) as a marker for the production of gynogenetic rainbow trout (Salmo gairdneri). Theor. Appl. Genet. 72: 633-636.

Chourrout, D., and Happe, A. 1986. Improved methods of direct chromosome preparation in rainbow trout, Salmo gairdneri. Aquaculture, 52: 255-261.
Day, R., and Stevenson, F. 1989. Evaluation of muskellunge in Clear Fork Reservoir. Final report of management evaluation conducted under Federal Aid Fish Restoration Project Nos. R-29-R-23 - R29-R28. Ohio Department of Natural Resources, Columbus, Ohio.

Dombeck, M.P., Menzel, B.W., and Hinz, P.N. 1984. Muskellunge spawning habitat and reproductive success. Trans. Am. Fish. Soc. 113: $205-216$.

Dunham, R.A. 1990. Production and use of monosex or sterile fishes in aquaculture. Aquatic Sciences 2: 1-17.

Galat, D. 1973. Normal embryonic development of the muskellunge (Esox masquinongy). Trans. Am. Fish. Soc. 102: 384-391.

Ihssen, P.E., McRay, L.R., McMillan, I., and Phillips, R.B. 1990. Ploidy manipulation and gynogenesis in fishes: cytogenetic and fisheries applications. Trans. Am. Fish. Soc. 119: 698-717.

Kligeman, A.D., and Bloom, S.E. 1977. Rapid chromosome preparations from solid tissues of fishes. J. Fish. Res. Board Can. 34: 266-269.

Komen, J., Duynhouwer, J., Richter, C.J.J., and Huisman, E.A. 1988. Gynogenesis in common carp (Cyprinus carpio L.). I. Effects of genetic manipulation of sexual products and incubation condition of eggs. Aquaculture, 69: 227-239.

Kuchnow, K.P., and Foster, R.S. 1976. Thermal tolerance of stored Fundulus heteroclitus gametes: fertilizability and survival of embryos. J. Fish. Res. Board Can. 33: 676-680.

Leslie, J.K., and Gorrie, J.F. 1984. Early development of the muskellunge, Esox masquinongy, of Stony Lake, Ontario. Can. Tech. Rep. Fish. Aquat. Sci. 1319. pp. 1-20.

Lin, F, and Dabrowski, K. 1996. Characteristics of muskellunge spermatozoa. II. Effects of ions and osmolality on sperm motility. Trans. Am. Fish. Soc. 125: 195-202.

Lin, F., Ciereszko, A., and Dabrowski, K. 1996. Sperm production and cryopreservation in muskellunge after carp pituitary extract and human chorionic gonadotropin injection. Prog. Fish-Cult. 58: 32-37.

Luczynski, M.J., and Woznicki, P. 1995. Preliminary observations on induced triploidy by heat shock in northern pike (Esox lucius L.). Arch. Rybactwa Pol. 3: 181-86.

Malison, J.A., Kayes, T.B. Held, J.A., Barry, T.P., and Amundson, C.H. 1993. Manipulation of ploidy in yellow perch (Perca flave. scens) by heat shock, hydrostatic pressure shock, and spermato. zoa inactivation. Aquaculture, 110: 229-242.

McGregor, J.F. 1970. The chromosomes of the maskinonge (Esox masquinongy). Can. J. Genet. Cytol. 12: 224-229.

Phillips, R.B., Zajicek, K.D., Ihssen, P.E., and Johnson, O. 1986. Application of silver staining to the identification of triploid fish cells. Aquaculture, 54: 313-319.

Rab, P., and Crossman, E.J. 1994. Chromosomal NOR phenotypes in North American pikes and pickerels, genus Esox, with notes on the Umbridae (Euteleostei: Esocae). Can. J. Zool. 72: 1951-1956.

Scott, W.B., and Crossman, E.J. 1973. Freshwater fishes of Canada. Bull. Fish. Res. Board Can. 184.

Shelton, W.L. 1986. Broodstock development for monosex production of grass carp. Aquaculture, 57: 311-319.

Sola, L., Arcangeli, R., and Cataudella, S. 1986. Nucleolus organizer chromosomes in a teleostean species of tetraploid origin, Cyprinus carpio. Cytogenet. Cell Genet. 42: 183-186.

Stoss, J. 1983. Fish gamete preservation and spermatozoa physiology. In Fish physiology. Vol. 9B. Edited by W.S. Hoar, D.J. Randall, and E.M. Donaldson. Academic Press, New York, N.Y. pp. 305-350.

Thorgaard, G.H. 1983. Chromosome set manipulation and sex control in fish In Fish physiology. Vol. 9B. Edited by W.S. Hoar, D.J. Randall, and E.M. Donaldson. Academic Press, New York, N.Y. pp. $405-434$.

Varadaraj, K. 1990. Production of diploid Oreochromis mossambicas gynogenesis using heterozygous sperm of Cyprinus carpio. Indian J. Exp. Biol. 28: 701-705. 